\title{
RADIOCARBON AND STABLE ISOTOPES AS GROUNDWATER TRACERS IN THE DANUBE RIVER BASIN OF SW SLOVAKIA
}

\author{
P P Povinec ${ }^{1,2} \bullet$ Z Ženišová $^{3}$ A S Šivo ${ }^{1} \cdot \mathrm{N}_{\text {Ogrinc }}^{4} \bullet$ M Richtáriková $^{1}$ R Breier ${ }^{1}$ \\ ABSTRACT. Horizontal and vertical variations in the distribution of ${ }^{14} \mathrm{C}, \delta^{13} \mathrm{C}, \delta^{18} \mathrm{O}$, and $\delta^{2} \mathrm{H}$ in groundwater of Žitný Island \\ (Rye Island) have been studied. Žitný Island, situated in the Danube River Basin, is the largest island in Europe that is formed \\ by interconnected rivers. It is also the largest groundwater reservoir in central Europe ( $\sim 10^{10} \mathrm{~m}^{3}$ of drinking water). The $\delta^{2} \mathrm{H}$ \\ vs. $\delta^{18} \mathrm{O}$ plot made from collected groundwater samples showed an agreement with the Global Meteoric Water Line. In the \\ eastern part of the island, it was found that subsurface water profiles (below $10 \mathrm{~m}$ water depth) showed enriched $\delta^{18} \mathrm{O}$ levels, \\ which were probably caused by large evaporation losses and the practice of irrigating the land for agriculture. The core of the \\ subsurface ${ }^{14} \mathrm{C}$ profile represents contemporary groundwater with ${ }^{14} \mathrm{C}$ values $>80 \mathrm{pMC}$, indicating that the Danube River dur- \\ ing all its water levels feeds most of the groundwater of Žitný Island. However, on the eastern part of the island a small area \\ was found where the $\delta^{13} \mathrm{C}$ and ${ }^{14} \mathrm{C}$ data (down to $\sim 30 \mathrm{pMC}$ ) helped to identify a groundwater aquifer formed below the Neogene \\ clay sediments. This is the first time that vertical distributions of isotopes in different groundwater horizons have been studied.
}

\section{INTRODUCTION}

Radiocarbon and stable isotopes have been used to address key aspects of groundwater origin, its dynamics and interconnections with different elements of the water cycle (Aggarwal et al. 2006a,b). The distribution of water isotopes in the atmosphere, precipitation, river water, and groundwater helped to trace past isotopic compositions affecting many processes, such as atmospheric circulation, rain and snow formation, groundwater formation, ecology, and paleoclimatology (Gonfiantini et al. 1999; Kendall and McDonnell 1999).

Radioactive and stable isotopes have been widely applied in groundwater studies to better understand groundwater formation, infiltration areas, groundwater dynamics, its age and vulnerability to contamination (Geyh and Wendt 1965; Vogel 1970; Fontes and Garnier 1979; Geyh 1991, 2004; Gonfiantini et al. 1999; Aggarwal et al. 2006b). In coastal regions, isotopes contributed to the literature of groundwater-seawater interactions, infiltration of saline waters to groundwater reservoirs, and better management of freshwater resources (Povinec et al. 2006, 2008, 2012; Schiavo et al. 2007, 2009).

A specific case in groundwater research has been represented by application of radioactive and stable isotopes in the Danube River Basin. The Danube River plays a dominant role in the groundwater system of central Europe, especially as its main water supply body, but also as its possible source of pollution (Rank et al. 1995; Böhlke et al. 1997; Stute et al. 1997). In this respect, isotope groundwater research in Slovakia was mostly based on stable isotopes (Malík et al. 1995; Michalko 1999). Recently, however, several ${ }^{14} \mathrm{C}$ studies were carried out on groundwater, especially on mineral and thermal waters (Franko et al. 2008; Povinec et al. 2009, 2010).

Our aim here is to study the isotopic composition of Žitný Island (southwestern Slovakia) groundwater, which would assist later in the vulnerability assessment of this largest central European source of drinking water against possible pollution from industrial and agricultural sources. We report results on the horizontal and vertical distribution of ${ }^{14} \mathrm{C}$ and stable isotopes $\left({ }^{18} \mathrm{O}\right.$ and $\left.{ }^{13} \mathrm{C}\right)$ in groundwater of Žitný Island (Žitný ostrov), which will help us to better understand the distribution

${ }^{1}$ Centre for Nuclear and Accelerator Technologies (CENTA), Department of Nuclear Physics and Biophysics, Faculty of Mathematics, Physics and Informatics, Comenius University, SK-84248 Bratislava, Slovakia.

${ }^{2}$ Corresponding author. Email: povinec@fmph.uniba.sk.

${ }^{3}$ Department of Hydrology, Faculty of Natural Sciences, Comenius University, Bratislava, Slovakia.

${ }^{4}$ Jožef Stefan Institute, Ljubljana, Slovenia.

(c) 2013 by the Arizona Board of Regents on behalf of the University of Arizona

Proceedings of the 21st International Radiocarbon Conference edited by A J T Jull \& C Hatté

RADIOCARBON, Vol 55, Nr 2-3, 2013, p 1017-1028 


\section{PP Povinec et al.}

of isotopes in the groundwater reservoir, and to assess the impact of the Danube River on the groundwater regime in the region. These data represent the first results on the vertical distribution of isotopes in different groundwater horizons.

\section{GEOLOGY AND HYDROGEOLOGY BACKGROUND}

Žitný Island, with an area of $1200 \mathrm{~km}^{2}$, is part of the Danube River Basin, covering the territory between the Danube River to the south, the Little Danube River (Malý Dunaj) to the north, and the Váh River to the east (Figure 1). It is the largest island in Europe that is formed by interconnected rivers. The core of Žitný Island is the Gabčíkovo depression situated at its center, which is bordered to the NW by the Small Carpathians, and to the SE by a system of faults that regulate increasing thickness of Quaternary sediments to the center of the depression (Figure 2; Mahel' 1983). From the NW, the base of the Quaternary Gabčíkovo depression decreases to a depth of 450-500 m (the deepest layers were found in boreholes at Gabčíkovo, $460 \mathrm{~m}$ ). The Quaternary sub-base is made of ruman, dak, and pont sediments, mostly of gray up to gray-green, weakly calcinated mica clays and dust with varying an admixture of sand (Mucha et al. 2004). The territory of Žitný Island is formed from the Quaternary deposits (Maglay et al. 2009) forming terraces of fluvial sediments (clayey sands, sands, gravels, sand gravels, and residual sands), and bottom-lands of fluvial sediments (sandy clays, clays, clayey sands, and clayey gravels).
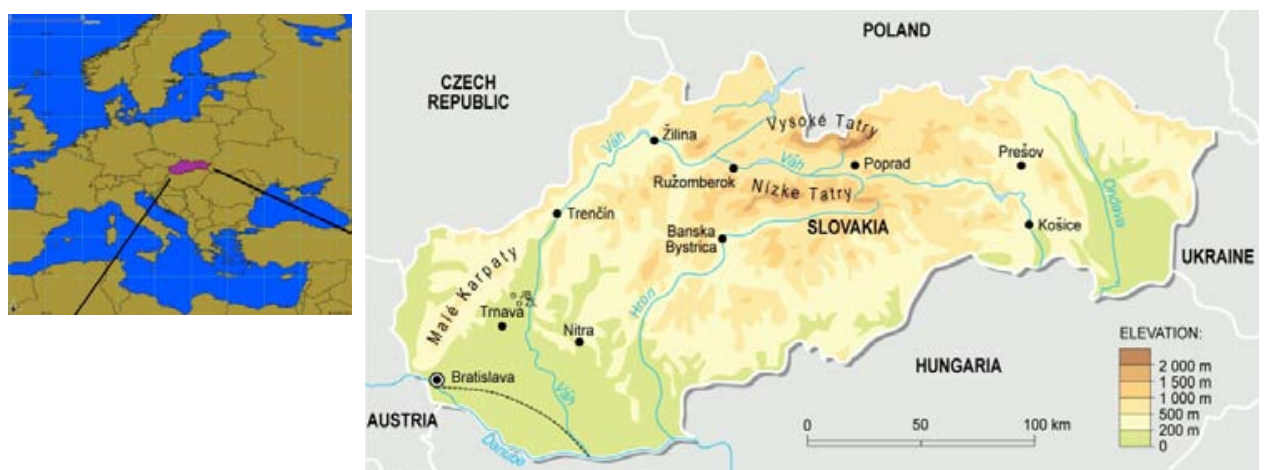

Figure 1 The map of Slovakia (left) with topography and the main river system (right). Žitný Island (marked by the dashed line) is located in SW Slovakia, bordered by the Danube River to the south, the Little Danube to the north, and the Váh River to the east.

The Quaternary sediments of Žitný Island could be allocated to the lower, middle, and upper Pleistocene, and the Holocene. The lower Pleistocene is characterized by limnic and fluvial-limnic sediments. A complex of middle Pleistocene sediments is denoted as the Danube gravel formation. Its thickness south of Bratislava is 10-20 m, at Komárno 8-12 m, and in the center of the depression around Gabčíkovo it is $\sim 160 \mathrm{~m}$. The sediments are mostly made of coarse gravels, sand gravels, and sands without fine fractions, which indicate the dominance of streambed facies over bottom-land sediments. The gravel material has characteristic rusty-brown, brown-yellow, and gray coatings. The upper Pleistocene is formed by fluvial gravel-sand strata (a bottom accumulation of rivers). At the turn of the Pleistocene and Holocene, fluvial strata and aggradation walls were formed (mainly the elevated core of Žitný Island between Podunajské Biskupice and Komárno), which are sinking below the Holocene sediments. While at the northern part of Žitný Island the Holocene width reaches $15 \mathrm{~km}$, at the southern part it is only $4-6 \mathrm{~km}$, or it is manifested as sub-islands. Aggradation walls are made from fine- to middle-grained sands, elevated by 3-4 m above the terrene. The Holocene sediments are formed by a diluvium enclosure of river bottom-lands with an admixture of 


\section{Groundwater Tracers in the Danube River Basin}

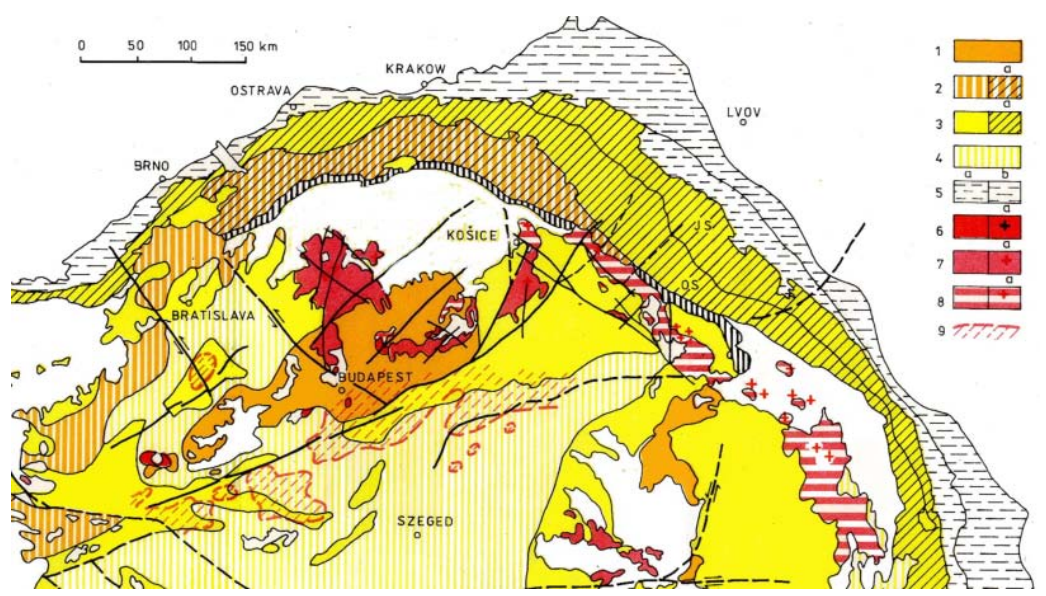

Figure 2 Map of volcanic and tectonic basins of central Europe (Mahel' 1983): 1 - Paleogene basins; 2 - after-Savian basins; 3 - after-Stirian basins; 4 - Pliocene basins; 5 - Front crease; 6 - early-late geosynclinal volcanic; 7 - late geosynclinal Miocene volcanic; 8 - late geosynclinal Pliocene volcanic; 9 - large underground bodies of Miocene volcanic.

gravel, recent, and fossil soils. The Danube basin is divided by a system of longitudinal and transversal faults, separating the areas on a system of rafts, which were and still are sinking with differing intensity. The raft composition of the Gabčíkovo depression is a result of the youngest Quaternary phase of its neotectonic development (Pospiśsil et al. 1978).

Žitný Island represents a flat terrain situated 136-129 m above sea level. The average yearly precipitation in Bratislava during 1951-1980 was $580 \mathrm{~mm}$. The average yearly evaporation from the soil surface at Žitný Island for the time interval 1961-1990 was $500 \mathrm{~mm}$. A total potential evaporation was between 700 and $800 \mathrm{~mm}$.

The groundwater regime of Žitný Island is a result of interactions between Danube water (and other surface water bodies such as the Little Danube to the north, and Váh River to the east of the island) and groundwater in the region, as well as with precipitation and evaporation. A general trend in the flow of groundwater is mostly following the main rivers in the region (Danube, Little Danube, and Váh). Precipitation influences groundwater regime especially during summer, in connection with elevated flow rates in rivers, and also by increasing the groundwater level (with different delays depending on the distance from the river).

Hydrogeological regionalization divides the Žitný Island (Figure 2) into 2 regions of groundwater occurrence in Quaternary sediments:

- Intergranular groundwater Quaternary alluvia in the western part of the Danube Basin (the Danube River drainage basin; surface of $519 \mathrm{~km}^{2}$ ), formed by alluvial and terrace gravels, sand gravels, and Holocene sands;

- Intergranular groundwater Quaternary alluvia in the eastern part of the Danube basin (the Váh River drainage basin, surface of $1668 \mathrm{~km}^{2}$ ), formed by alluvial and terrace gravels, sand gravels, and Holocene sands.

The most complex evaluation of the hydrogeological situation at Žitný Island has been covered in the hydrogeological map of the Danube basin. This map is based on the evaluation of 812 boreholes, indicating a uniform abundance of the Quaternary collector, made of sand gravels (Malík et al. 1995). 


\section{PP Povinec et al.}

Monitoring of the groundwater quality carried out by the Slovak Hydrometeorological Institute (SHMU) divides the Žitný Island into 6 sectors (Figure 3; Luptáková et al. 2007):

$$
\begin{aligned}
& 51 \text { - a right-riverside of the Danube River; } \\
& 52 \text { - a left-riverside of the Danube River; } \\
& 53 \text { - an upper (western) part of Žitný Island; } \\
& 54 \text { - a middle (central) part of Žitný Island; } \\
& 55 \text { - a lower (eastern) part of Žitný Island; } \\
& 56 \text { - a riverside of the Little Danube River. }
\end{aligned}
$$

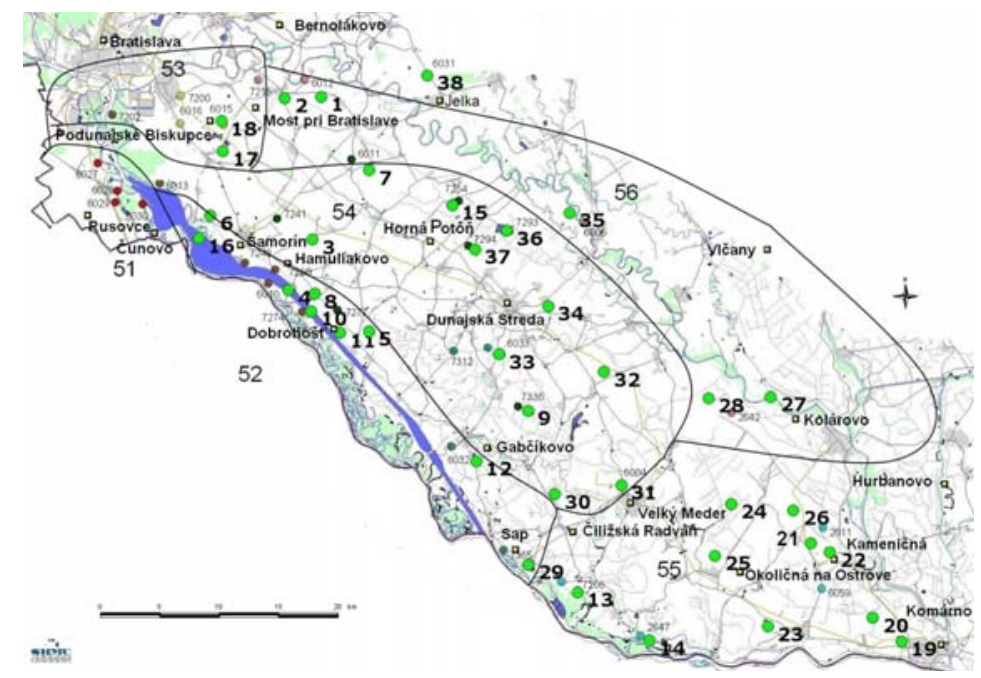

Figure 3 Sampling sites of groundwater boreholes on Žitný Island

The groundwater regime has been considerably improved by the construction of a water power plant near Gabčíkovo (established in 1992), which produces 720 MW of electricity. The plant has also improved the Danube River shipping conditions and the ecological situation in the region. Due to the backwater effect, the level of groundwater in the region has increased (e.g. at Bratislava by $\sim 2 \mathrm{~m}$ ), which has had a positive impact on all ecosystems in the region.

The territory of Žitný Island is of great economical significance as it represents the largest reservoir of groundwater in central Europe $\left(\sim 10^{10} \mathrm{~m}^{3}\right.$, with potential of $\left.\sim 18 \mathrm{~m}^{3} \mathrm{~s}^{-1}\right)$. In 1987, Žitný Island was declared a nationally protected water resource territory of Slovakia. There are many groundwater sources situated in the are of Žitný Island that are delivering drinking water to Bratislava, as well as to many other places in southwestern Slovakia. Therefore, Žitný Island is the most important agricultural region in Slovakia because of its location, good soil, and climatic conditions.

\section{SAMPLES AND ANALYTICAL METHODS}

The sampling sites at Žitný Island were identical to groundwater sources regularly monitored by the Slovak Hydrometeorological Institute (L’uptáková et al. 2007) (Figure 3). Sampling campaigns were carried out in November 2008, June 2009, and October 2010 using operational boreholes, some of them allowing sampling at 2-4 horizons. The sampling of water from boreholes was carried out in such a way that inflows were isolated from their overlying and/or underlying strata. All pipes of 


\section{Groundwater Tracers in the Danube River Basin}

each borehole are cemented above perforation, so the borehole wells are technically prevented from inflows of water into the borehole from its sealed part. This, however, cannot prevent mixing of waters during their flow into the aquifer. Such cases can occur especially in discharge areas, when deep flow waters may be influenced by a shallow groundwater.

During groundwater sampling, in situ measurements of basic physical and chemical parameters (groundwater temperature, air temperature, $\mathrm{pH}$, electrical conductivity [EC], oxidation-reduction potential [Eh], concentration of dissolved oxygen, and oxygen saturation) were carried out as well. Radiocarbon analyses were performed for DIC of groundwater samples of about $50 \mathrm{~L}$ in volume, directly collected from the boreholes. Bicarbonates were extracted as soon as possible on a sampling site by precipitation with barium chloride. The produced $\mathrm{BaCO}_{3}$ was stored in polyethylene containers and transported to the laboratory. Simultaneously, small-volume water samples $(1 \mathrm{~L})$ were collected for analysis of tritium and stable isotopes. Table S1 (online Supplementary file) describes the groundwater sampling sites.

Laboratory analyses included: analysis of stable isotopes $\left({ }^{2} \mathrm{H},{ }^{18} \mathrm{O},{ }^{13} \mathrm{C}\right)$, preparation of gas fillings, and ${ }^{14} \mathrm{C}$ activity measurement. A few $\mathrm{mL}$ of carbon dioxide liberated from the $\mathrm{BaCO}_{3}$ sample was used for determination of the isotopic ratio of ${ }^{13} \mathrm{C} /{ }^{12} \mathrm{C} . \delta^{13} \mathrm{C}$ values are expressed relative to the VPDB standard (in \%o). The ${ }^{18} \mathrm{O} /{ }^{16} \mathrm{O}$ isotopic ratio was analyzed directly in water samples. $\delta^{18} \mathrm{O}$ data are reported relative to Vienna Standard Mean Ocean Water (VSMOW, in \%o). Relative uncertainties were below $0.2 \%$ o (at $1 \sigma)$. The ${ }^{2} \mathrm{H} / \mathrm{H}$ isotopic ratio was also determined directly from water samples and data reported relative to VSMOW using conventional $\delta$ notation in \%. The precision of measurements $(1 \sigma)$ was $\pm 1 \%$. The mass spectrometry analyses of stable isotopes were carried out at the Geological Institute of Dionýz Štúr (Bratislava) and at the Jožef Stefan Institute (Ljubljana).

For ${ }^{14} \mathrm{C}$ analysis, $\mathrm{CO}_{2}$ was released from barium carbonate samples by addition of $\mathrm{H}_{3} \mathrm{PO}_{4}$. Methane (Povinec 1972) synthesized from $\mathrm{CO}_{2}$ was used as a filling gas of the low-level proportional counter (Povinec 1978). Measurement time for the samples was 40-60 hr. In addition to water samples, samples of background and of ${ }^{14} \mathrm{C}$ oxalic acid standard produced by NIST (National Institute of Standards and Technology, Gaithersburg, USA) were analyzed. ${ }^{14} \mathrm{C}$ results are expressed as percent modern carbon (pMC) relative to the NIST ${ }^{14} \mathrm{C}$ standard. All ${ }^{14} \mathrm{C}$ data were corrected for $\delta^{13} \mathrm{C}$. Relative uncertainties of ${ }^{14} \mathrm{C}$ analyses were below $10 \%$ (at $1 \sigma$ ). ${ }^{14} \mathrm{C}$ analyses were carried out in the Department of Nuclear Physics of the Faculty of Mathematics, Physics and Informatics of the Comenius University in Bratislava, which has over $45 \mathrm{yr}$ of experience in ${ }^{14} \mathrm{C}$ measurements (Povinec et al. 1968; Usačev et al. 1973). Quality management of all analyses has been assured by analysis of reference materials and by participation in intercomparison exercises.

\section{RESULTS AND DISCUSSION}

The results of ${ }^{2} \mathrm{H},{ }^{18} \mathrm{O},{ }^{13} \mathrm{C}$, and ${ }^{14} \mathrm{C}$ analyses of the collected groundwater samples are presented in Table S2 (online Supplementary file).

\section{Plotting $\delta^{2} \mathrm{H}$ vs. $\delta^{18} \mathrm{O}$}

Figure 4 shows the $\delta^{2} \mathrm{H}$ vs. $\delta^{18} \mathrm{O}$ plot for the collected groundwater samples at Žitný Island, compared with the Global Meteoric Water Line (GMWL) defined after Craig (1961) as

$$
\delta^{2} \mathrm{H}=8 \delta^{18} \mathrm{O}+10
$$

which describes the present-day atmospheric precipitation according to oxygen and hydrogen isotope content. It can be seen that most of the groundwater data fit well on the GMWL, evidence thus 


\section{PP Povinec et al.}

of groundwater recharge from modern atmospheric precipitation, or from the Danube River. The $\delta^{18} \mathrm{O}$ and $\delta^{2} \mathrm{H}$ values in the groundwater vary from -12.22 to $-9.10 \%$ and from -86.88 to $-63.10 \%$, respectively. The samples with enriched $\delta^{18} \mathrm{O}$ values (up to -9.10\%) are mostly below the GMWL, characterizing shallow groundwater formed by modern precipitation, which was mixed with the water undergoing evaporation on the surface or during its infiltration. The majority of samples have $\delta^{18} \mathrm{O}$ values within the interval $-11.3 \%$ and $-10 \%$, similar to the Danube River water (values between $-12.4 \%$ and $-10.2 \%$; Michalko et al. 2011). Unfortunately, we do not have isotopic data available for precipitation that would allow us to draw a local meteoric water line.

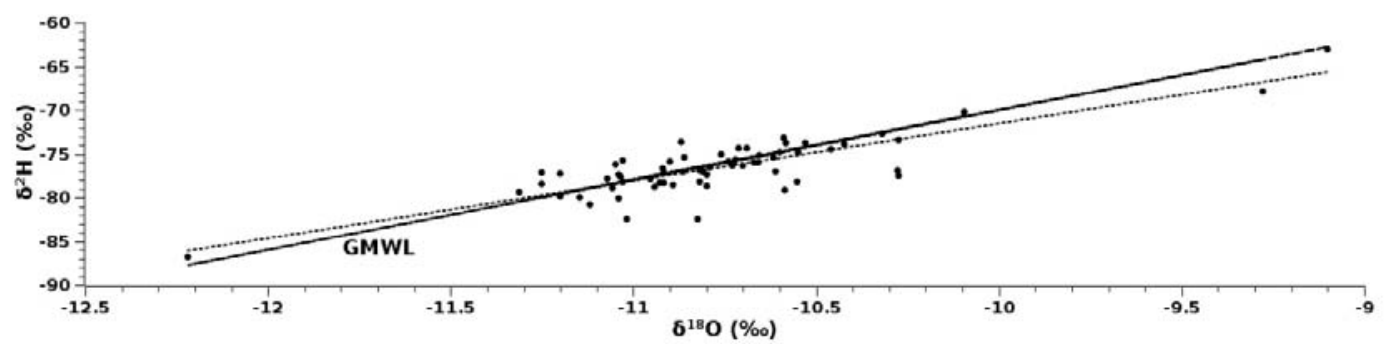

Figure 4 The $\delta^{2} \mathrm{H}$ vs. $\delta^{18} \mathrm{O}$ plot for the collected groundwater samples on Žitný Island (the dashed line represents a linear fit through the data).

\section{Spatial and Vertical Distribution of Isotopes in Groundwater}

The distribution of $\delta^{18} \mathrm{O}$ in the shallow groundwater of Žitný Island (up to $20 \mathrm{~m}$ depth) is shown in Figure 5. The $\delta^{18} \mathrm{O}$ values varied between -12.22 and $-9.10 \%$, however, there are still large regional gaps; therefore, more data are required to assure reasonable data density. Generally, it can be seen that in the eastern part of Žitný Island the water samples were enriched in $\delta^{18} \mathrm{O}$ (up to -9.1\%o), while the rest of the region shows depleted values (down to -11.3\%), except borehole no. 21 (Figure 3, Table S2) where the most depleted value was measured (-12.22\%o). This shows well other special characteristics (e.g. very low ${ }^{14} \mathrm{C}$ content), as we shall discuss later. Most of the data, however, are in agreement with $\delta^{18} \mathrm{O}$ data measured for the Danube River (values between -12.4 and $-10.2 \%$; Michalko et al. 2011), except the enriched values (above -10.2\%o) measured at shallow depths (up to $\sim 10 \mathrm{~m}$ ) on the east of the island (a box of $47.8-47.9^{\circ} \mathrm{N}$ and $17.8-18.1^{\circ} \mathrm{E}$ ). This may be because larger evaporation losses as river runoff is negligible in this region ( $\sim 90 \%$ of loss in the water balance is due to evaporation; MESR 2002). Another source of enriched $\delta^{18} \mathrm{O}$ may be land irrigation, which has often been used in this agriculturally heavily industrialized region. During hot summer seasons, the water used for irrigation evaporates from the land surface, so water with a heavier isotopic signature penetrates into the groundwater. The enrichment of subsurface groundwater with $\delta^{18} \mathrm{O}$ is also accompanied by enrichment of $\delta^{2} \mathrm{H}$ in these waters, as is documented in the $\delta^{2} \mathrm{H}$ vs. $\delta^{18} \mathrm{O}$ graph presented in Figure 4.

Figure 5 also presents the vertical distribution of $\delta^{18} \mathrm{O}$ in groundwater of Žitný Island with latitude and longitude. The observed range of $\delta^{18} \mathrm{O}$ for water depth between 20 and $90 \mathrm{~m}$ was from $-11.31 \%$ to $-10.27 \%$. While the deeper samples (up to $90 \mathrm{~m}$ water depth) were depleted in $\delta^{18} \mathrm{O}$ values, generally below $-10.3 \%$, similar to the Danube River values, the subsurface core observed at the eastern part of the island at $\sim 10 \mathrm{~m}$ water depth showed enriched $\delta^{18} \mathrm{O}$ values from -10.0 and $-9.10 \%$, as previously discussed. However, the samples collected at the central-northern part of the island again show depleted $\delta^{18} \mathrm{O}$ values, close to the values observed for the Danube River (although in this case they could be under an influence of the Little Danube). 


\section{Groundwater Tracers in the Danube River Basin}

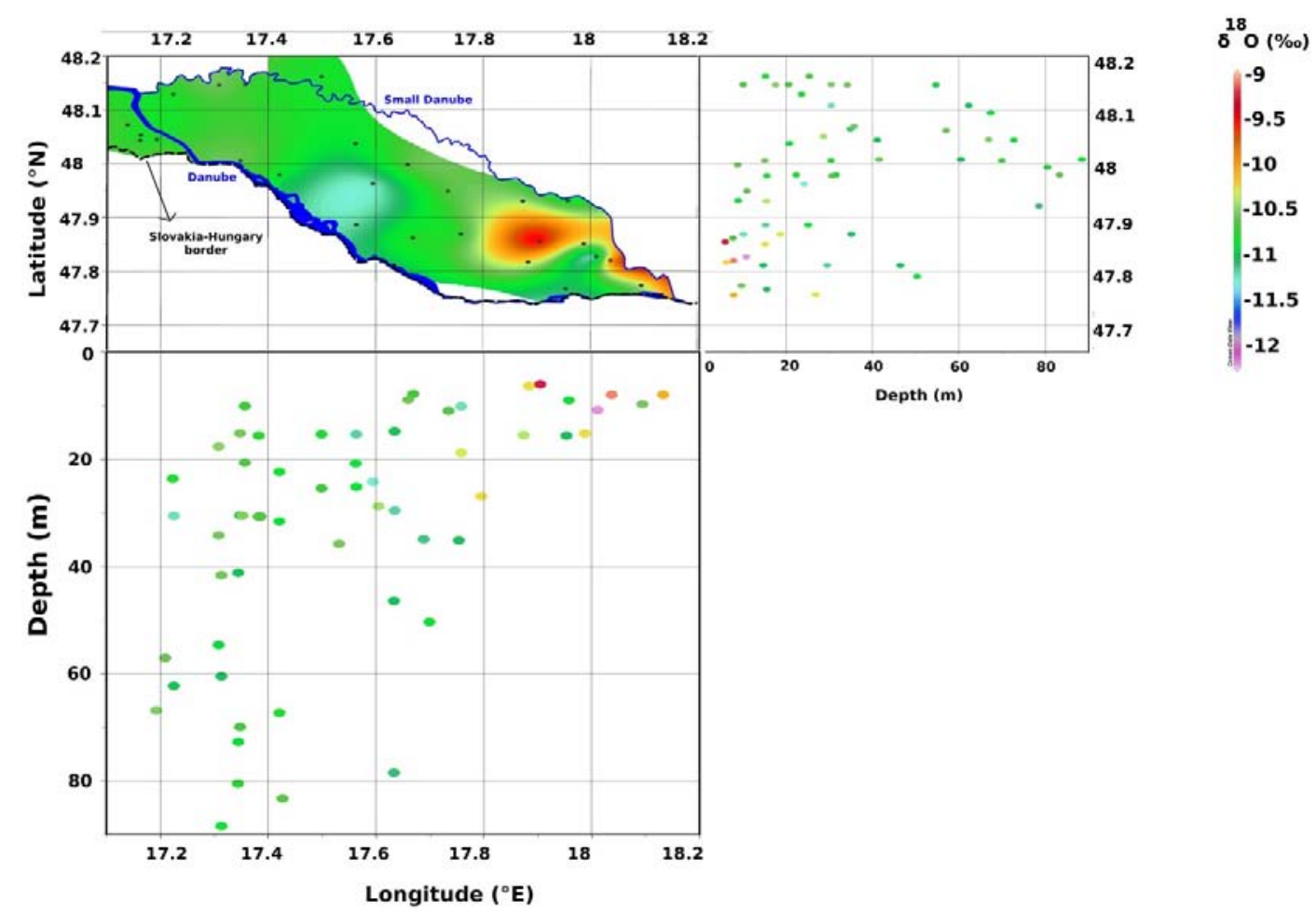

Figure 5 Spatial and vertical distribution of $\delta^{18} \mathrm{O}$ with latitude and longitude in groundwater of Žitný Island

The $\delta^{18} \mathrm{O}$ groundwater data presented in this paper are in reasonable agreement with data measured for the Danube River (Michalko et al. 2011), which supports the idea that the Danube River system is the main source of groundwater observed at Žitný Island, even at water depths down to $90 \mathrm{~m}$. The spatial distribution of $\delta^{13} \mathrm{C}$ results is presented in Figure 6. The $\delta^{13} \mathrm{C}$ values in shallow groundwater (down to $20 \mathrm{~m}$ water depth) varied between $-17.37 \%$ and $-11.08 \%$. Most of the western part of the island showed enriched $\delta^{13} \mathrm{C}$ values; the eastern part showed mostly depleted values.

The $\delta^{13} \mathrm{C}$ groundwater profiles with latitude and longitude in the depth interval 20-90 m, also presented in Figure 5, have a different distribution. The most depleted $\delta^{13} \mathrm{C}$ levels (-19.22\% at $\left.35.8 \mathrm{~m}\right)$ we see at the central part of the island (sector 54, borehole no. 15), and then in the eastern part of the island $(-17.53 \%$ at $50.3 \mathrm{~m}$, sector 55 , borehole no. 13$)$. The central and eastern parts of the island also showed enriched values of $-10.66 \%$ at a depth of $78.5 \mathrm{~m}$ (borehole no. 9), and of $-10.62 \%$ at $35.1 \mathrm{~m}$ (borehole no. 31).

Large variations in groundwater $\delta^{13} \mathrm{C}$ values are typical for Quaternary aquifers with a large amount of carbonate materials. Largest $\mathrm{HCO}_{3}{ }^{-}$contents were observed in the eastern part of the island (sector 55, which is represented by the Neogene clay sediments; Maglay et al. 2009) in boreholes no. 24 (619 mg/L), no. 22 (607 mg/L), no. 19 (582 mg/L), and no. 23 (531 mg/L), with corresponding $\delta^{13} \mathrm{C}$ values of $-12.15 \%$, $-15.86 \%$, $-15.86 \%$, and $-11.48 \%$, respectively. The increased levels of free $\mathrm{CO}_{2}$ were also observed in sector 55, in boreholes no. $26(36.2 \mathrm{mg} / \mathrm{L})$, no. $14(32.7 \mathrm{mg} / \mathrm{L})$, and no. $21(29.6 \mathrm{mg} / \mathrm{L})$ with corresponding $\delta^{13} \mathrm{C}$ values of $-12.04 \%$, $-17.53 \%$, and $-11.08 \%$, respectively, also accompanied with high $\mathrm{HCO}_{3}{ }^{-}$levels of 476, 452, and $352 \mathrm{mg} / \mathrm{L}$, respectively. The enriched $\delta^{13} \mathrm{C}$ values would indicate a closed groundwater system with respect to $\mathrm{CO}_{2}$; however, 


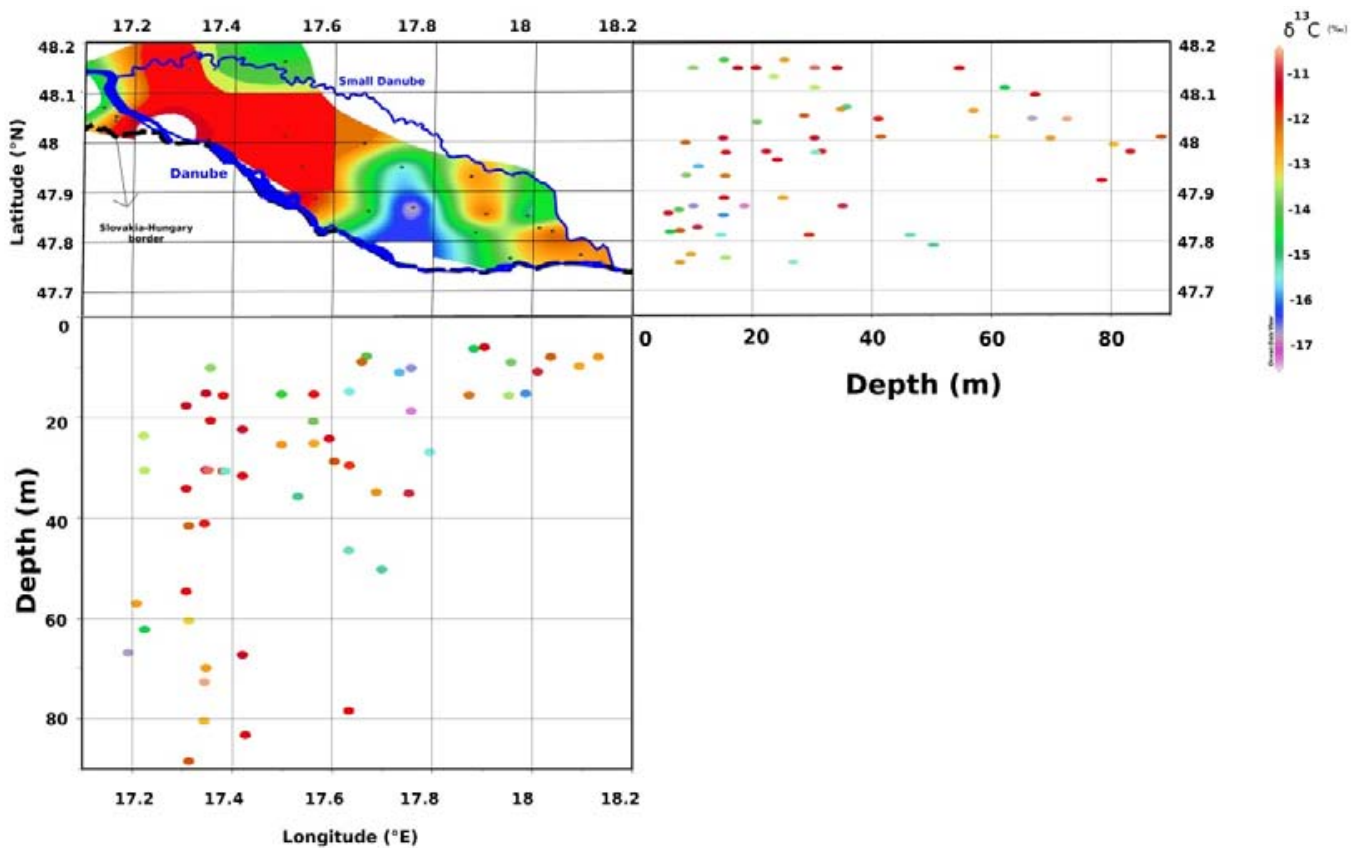

Figure 6 Spatial and vertical distribution of $\delta^{13} \mathrm{C}$ with latitude and longitude in groundwater of Žitný Island

borehole no. 13 with very depleted $\delta^{13} \mathrm{C}$ content does not fit into this system. We shall discuss in more detail the distribution of $\delta^{13} \mathrm{C}$ in groundwater profiles together with the ${ }^{14} \mathrm{C}$ data.

The spatial distribution of ${ }^{14} \mathrm{C}$ in shallow groundwater of Žitný Island (down to $20 \mathrm{~m}$ depth) is presented in Figure 7. The observed values are mostly $>80$ pMC, except wells no. 21 (depth $10.9 \mathrm{~m}$ ) and no. 26 (at $15.2 \mathrm{~m}$ ) on the east side of the island where the ${ }^{14} \mathrm{C}$ values of 31.5 and $69.9 \mathrm{pMC}$, respectively, were obtained. The ${ }^{14} \mathrm{C}$ water profile data showed a similar distribution with 2 eastern boreholes having lower ${ }^{14} \mathrm{C}$ content (no. 13 with $43.8 \mathrm{pMC}$ at $50.3 \mathrm{~m}$ and borehole no. 31, $63.0 \mathrm{pMC}$ at $35.1 \mathrm{~m}$ ), indicating that in this region we are dealing with a groundwater reservoir that has been outside of the direct influence of the Danube River. The core of the ${ }^{14} \mathrm{C}$ profiles represents, however, modern groundwater as the majority of groundwater has ${ }^{14} \mathrm{C}$ content above $80 \mathrm{pMC}$.

To investigate the relationship between the carbon isotopes in DIC of groundwater, we present a $\delta^{13} \mathrm{C}$ vs. ${ }^{14} \mathrm{C}$ plot in Figure 8. There are 2 boreholes in the eastern part of the island that are separated from the other boreholes, and which show interesting characteristics. Borehole no. 21 shows the lowest ${ }^{14} \mathrm{C}$ content (31.5 pMC), supported by high free $\mathrm{CO}_{2}$ content $(29.6 \mathrm{mg} / \mathrm{L})$, relatively high $\mathrm{HCO}_{3}{ }^{-}$content $(352 \mathrm{mg} / \mathrm{L})$, and a high $\delta^{13} \mathrm{C}$ value $\left(-11.08 \%\right.$ ). Borehole no. 13 has also low ${ }^{14} \mathrm{C}$ content (43.8 pMC), high free $\mathrm{CO}_{2}(32.7 \mathrm{mg} / \mathrm{L})$ and $\mathrm{HCO}_{3}{ }^{-}(452 \mathrm{mg} / \mathrm{L})$, but low $\delta^{13} \mathrm{C}$ value $(-17.53 \%$ ). The other boreholes from this region (i.e. no. 31, 26, and 23) have ${ }^{14} \mathrm{C}$ content below $73 \mathrm{pMC}$, and their characteristics also separate them from the majority of boreholes from the central and western parts of the island.

\section{Isotope Data and Hydrogeological Characteristics}

The isotopic composition of groundwater at Žitný Island may be explained by its hydrogeological characteristics. The hydrogeological collector of Žitný Island was formed by Quaternary fluvial sediments that were deposited in the region by the Danube River. The collector is filled mainly by grav- 


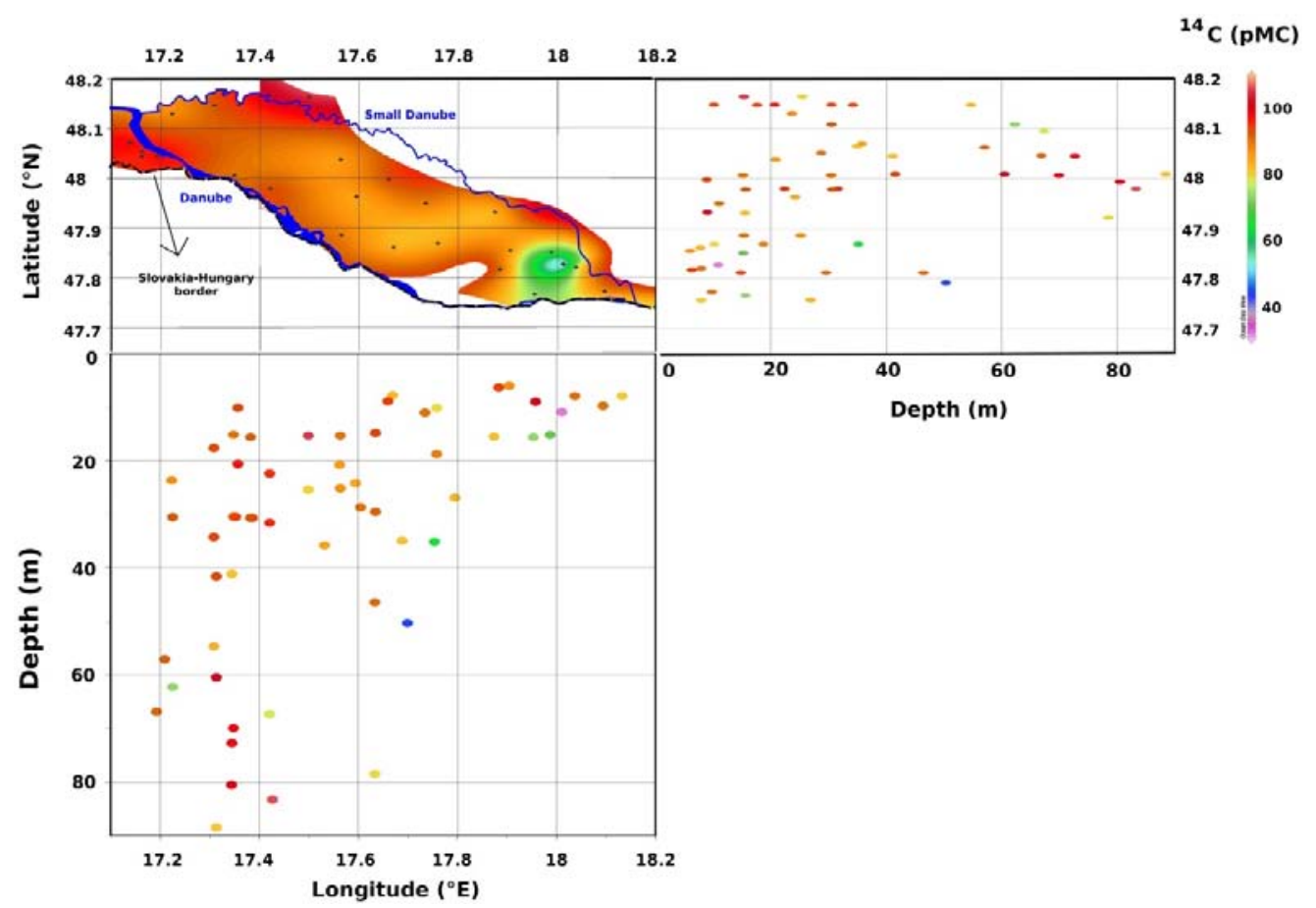

Figure 7 Spatial and vertical distribution of ${ }^{14} \mathrm{C}$ with latitude and longitude in groundwater of Žitný Island

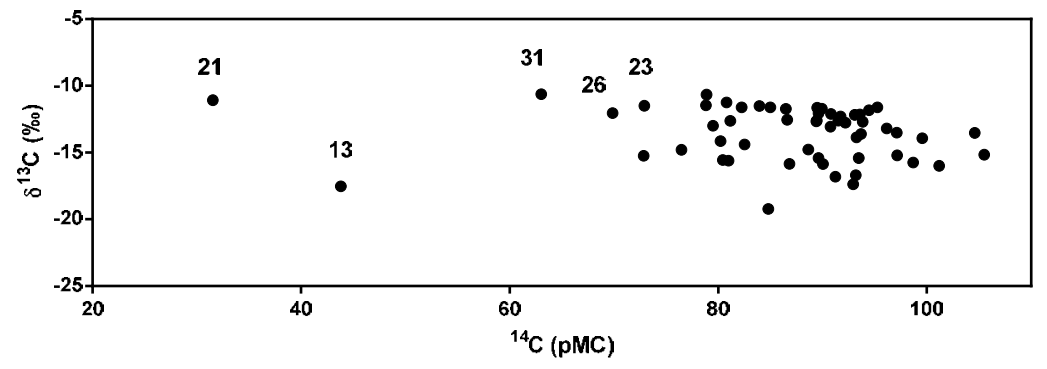

Figure 8 The $\delta^{13} \mathrm{C}$ vs. ${ }^{14} \mathrm{C}$ plot for the collected groundwater samples on Žitný Island

els, sand gravels, and sands. While at the central depression of the island (sector 54, Figure 3 ) the Quaternary sediments are almost $200 \mathrm{~m}$ thick, in the eastern part (sector 55) sediments are only a few meters below the surface. Due to the hydraulic connection between groundwater and the Danube River, the intensity, speed, and flow direction of groundwater at Žitný Island is influenced by the Danube River, which has been supported by the chemical (Benková et al. 2005) as well as isotopic composition of groundwater (Michalko et al. 2011; this paper). The groundwater levels at Žitný Island depend therefore on water levels (and flow volumes) in the Danube River. This has been well manifested in the central and western part of the island where the thickness of Quaternary sediment is tens (even hundreds) of meters. However, in the eastern part of the island (where groundwater with lower ${ }^{14} \mathrm{C}$ content was observed), Neogene clays were found a few meters below the surface (Maglay et al. 2009), which prevent a direct infiltration of groundwater of Danube origin to deeper layers. This would indicate the existence of a confined aquifer formed below the layer of 


\section{PP Povinec et al.}

Neogene clay sediments. This is not the case in the central and western parts of the island, where the Quaternary sediments are much thicker, and where mainly the Danube River system is directly influencing the groundwater regime of Žitný Island, even at depths down to $90 \mathrm{~m}$.

\section{Seasonal Variations in the Isotope Data}

It is well known that the isotopic composition of the Danube River water varies during the year, showing $\delta^{18} \mathrm{O}$ maxima (to $-10.2 \%$ ) in late autumn and winter, and deep minima (to $-12.4 \%$ ) in late spring and early summer (Pawellek et al. 2002; Michalko et al. 2011). The lighter isotopic composition is due to the influence of water from melting alpine snow, also causing high flow rates in the Danube River. For example in Bratislava, maximum flow rates up to $~ 10,400 \mathrm{~m}^{3} / \mathrm{s}$ were observed (minimum flow rates were $\sim 582 \mathrm{~m}^{3} / \mathrm{s}$; MESR 2002).

Unfortunately, our isotope data set is too small, and thus does not allow us to perform a detailed evaluation of seasonal variations. Our groundwater sampling campaigns at Žitný Island were carried out in November 2008, June 2009, and October 2010. However, we do not have isotope data available for the same sampling boreholes (and depths) during different seasons. A few boreholes that were sampled during different seasons show differences within $\pm 0.2 \%$, except borehole no. 31 , which shows depletion by $0.7 \%$ for the late spring sampling. We hope to draw a more precise picture of the distribution of stable isotopes and ${ }^{14} \mathrm{C}$ in groundwater of Žitný Island after more samples have been analyzed. Tritium analyses are underway as well, which will further help to evaluate the groundwater characteristics of Žitný Island.

\section{CONCLUSIONS}

The obtained results on spatial and vertical variability of ${ }^{14} \mathrm{C}, \delta^{13} \mathrm{C}$, and $\delta^{18} \mathrm{O}$ suggest isotopic heterogeneity in the groundwater of Žitný Island, although the data density is still not good enough to draw more precise conclusions. The main results may be summarized as follows:

1. The $\delta^{2} \mathrm{H}$ vs. $\delta^{18} \mathrm{O}$ plot made from collected groundwater samples showed an agreement with the Global Meteoric Water Line.

2. The enriched $\delta^{18} \mathrm{O}$ values observed in the eastern part of Žitný Island are characteristic of shallow groundwater formed from surface water that underwent evaporation on the surface or during its infiltration in the unsaturated zone. Most of the $\delta^{18} \mathrm{O}$ values observed in groundwater of Žitný Island represent, however, groundwater of Danube origin.

3. The $\delta^{13} \mathrm{C}$ vs. ${ }^{14} \mathrm{C}$ graph indicates that in the eastern part of the island (where ${ }^{14} \mathrm{C}$ levels below 63 pMC were observed), there exists a confined aquifer formed below the layer of Neogene clay sediments. The majority of ${ }^{14} \mathrm{C}$ groundwater data being above $80 \mathrm{pMC}$ indicates, however, groundwater of recent origin.

4. The majority of groundwater isotope data presented in this paper support the argument that the Danube River system has been the main source of groundwater observed at Žitný Island, even at water depths down to $90 \mathrm{~m}$.

This has been a first attempt to construct isotope maps and to study spatial and vertical distribution of isotopes in groundwater of Slovakia. We hope that this new research approach will improve the capability and efficiency of using isotopic tools for deeper evaluation, more rigorous assessment, and more efficient management of water resources in the region. 


\section{Groundwater Tracers in the Danube River Basin}

\section{ACKNOWLEDGMENTS}

Part of this research was supported by the IAEA (Research Contract No. 14301), and the EU Research and Development Operational Program funded by the ERDF (project No. 26240220004).

\section{REFERENCES}

Aggarwal PK, Gat JR, Froehlich KFO, editors. 2006a. Isotopes in the Water Cycle. Heidelberg: Springer.

Aggarwal P, Froehlich K, Gonfiantini R, Gat J. 2006b. Isotope hydrology: A historical perspective from the IAEA. In: Aggarwal PK, Gat JR, Froehlich KFO, editors. Isotopes in the Water Cycle. Heidelberg: Springer. p 3-8.

Benková K, Bodiš D, Nagy A, Maglay J, Švasta J, Černák R, Marcin D. 2005. A Basic Hydrogeology and Hydrogeochemistry Map of the Žitný Island. Bratislava: Report ŠGUDŠ. 267 p. In Slovak.

Böhlke JK, Révész K, Busenberg E, Deák J, Deseö E, Stute M. 1997. Groundwater record of halocarbon transport by the Danube River. Environmental Science \& Technology 31(11):3293-9.

Fontes J-C, Garnier J-M. 1979. Determination of the initial ${ }^{14} \mathrm{C}$ activity of the total dissolved carbon: a review of the existing models and a new approach. Water Resources Research 15(2):399-413.

Franko O, Šivo A, Richtáriková M, Povinec PP. 2008. Radiocarbon ages of mineral and thermal waters of Slovakia. Acta Physica Universitatis Comenianae 49: 125-32.

Geyh MA. 1991. The ${ }^{14} \mathrm{C}$ time-scale of groundwater. Correction and linearity. In: Isotope Techniques in Water Resources Development 1991. Vienna: IAEA. p 167-77.

Geyh MA. 2004. Radiocarbon dating of old groundwater: history, potential, limits and future. In: Isotope $\mathrm{Hy}$ drology and Integrated Water Resources Management. Vienna: IAEA. p 23-5.

Geyh MA, Wendt I. 1965. Results of water sample dating by means of the model by Münnich and Vogel. In: Proceedings of the Conference Radiocarbon and Tritium Dating. Pulmann. p 597-603.

Gonfiantini R, Froehlich K, Araguás-Araguás L. 1999. Isotopes in groundwater hydrology. In: Kendall C, McDonnell J, editors. Isotope Tracers in Catchment Hydrology. Amsterdam: Elsevier.

Kendall C, McDonnell J, editors. 1999. Isotope Tracers in Catchment Hydrology. Amsterdam: Elsevier.

Luptáková A, Žákovičová A, Kvapilová L, Molnár L', Jančár V, Mrafková L, Májovská A. 2007. Quality of Žitný Island Groundwater (2005-2006). Report SHMÚ, Bratislava. In Slovak.

Maglay J, Pristaš J, Kučera M, Ábelová M. 2009. Geological Map of the Quaternary Slovakia. Ministry of the Environment, Bratislava. In Slovak.

Mahel' M. 1983. Basic Structure of the Carpathian-Balcan Regions. Report GÚDŠ, Bratislava. In Russian.
Malík P, Michalko J, Mansell SJ, Fendeková M. 1995. Stable isotopes in karstic groundwaters of Vel'ká Fatra mountains, Slovakia. In: Proceedings of the International Symposium on Isotopes in Water Resources Management. Vienna: IAEA.

Michalko J. 1999. Stable isotopes of hydrogen, oxygen and sulphur in the waters of Slovakia. Slovak Geology Magazine 5:63-7.

Michalko J, Bodiš D, Malík P, Kordík J, Fajcíková K, Grolmusová Z, Veis P. 2011. Potential sources of strategic amounts of groundwater in the Bratislava region. Mineralia Slovaca 43:449-62.

Ministry of the Environment of Slovak Republic (MESR). 2002. Atlas of the Slovak Republic. Bratislava. 344 p. In Slovak.

Mucha I, Kocinger D, Hlavatý Z, Rodák D, Banský L, Lakatosová E, Hučárová K. 2004. Gabčíkovo Water Plant and the Environment. Bratislava: Podzemná voda. In Slovak.

Pawellek F, Freunstein F, Veizer J. 2002. Hydrochemistry and isotope geochemistry of the upper Danube River. Geochimica et Cosmochimica Acta 66:3839-54.

Pospísil P, Vass D, Melioris L, Repka T. 1978. Neotectonic basis of the Žitný Island and the adjacent territories. Mineralia Slovaca 10:443-56.

Povinec P. 1972. Preparation of methane gas filing for proportional ${ }^{3} \mathrm{H}$ and ${ }^{14} \mathrm{C}$ counters. Radiochemical and Radioanalytical Letters 9:127-35.

Povinec P. 1978. Multiwire proportional counters for low-level ${ }^{14} \mathrm{C}$ and ${ }^{3} \mathrm{H}$ measurements. Nuclear Instruments and Methods 156(3):441-5.

Povinec P, Šáro Š, Chudý M, Šeliga M. 1968. The rapid method of carbon-14 counting in atmospheric carbon dioxide. International Journal of Applied Radiation and Isotopes 19(12):877-81.

Povinec P, Aggarwal P, Aureli A, Burnett WC, Kontar EA, Kulkarni KM, Moore WS, Rajar R, Taniguchi M, Comanducci J-F, Cusimano G, Dulaiova H, Gatto L, Hauser S, Levy-Palomo I, Ozorovich YR, Privitera AMG, Schiavo MA. 2006. Characterisation of submarine ground water discharge offshore south-eastern Sicily - SGD Collaboration. Journal of Environmental Radioactivity 89(1):81-101.

Povinec PP, Oliveira J, Braga ES, Comanducci J-F, Gastaud J, Groening M, Levy-Palomo I, Morgenstern U, Top Z. 2008. Isotopic, trace element and nutrient characterization of coastal waters from Ubatuba inner shelf area, southeastern Brazil. Estuarine, Coastal and Shelf Science 76(3):522-42.

Povinec PP, Šivo A, Richtáriková M, Breier R, Lúčan L', 


\section{PP Povinec et al.}

Aggarwal PK, Araguás-Araguás L. 2009. Spatial distribution of isotopes in groundwater of Slovakia. Acta Physica Universitatis Comenianae 51:143-9.

Povinec PP, Franko O, Šivo A, Richtáriková M, Breier R, Aggarwal PK, Araguás-Araguás L. 2010. Spatial radiocarbon and stable carbon isotope variability of mineral and thermal waters in Slovakia. Radiocarbon 52(3):1056-67.

Povinec PP, Burnett WC, Beck A, Bokuniewicz H, Charette M, Gonneea ME, Groening M, Ishitobi T, Kontar E, Liong Wee Kwong L, Marie DEP, Moore WS, Oberdorfer JA, Peterson R, Ramessur N, Rapaglia J, Stieglitz T, Top Z. 2012. Isotopic, geophysical and biogeochemical investigation of submarine groundwater discharge: IAEA-UNESCO intercomparison exercise at Mauritius Island. Journal of Environmental Radioactivity 104:24-45.

Rank D, Pepesch W, Rainer V. 1995. Environmental isotope study at research landfill (Breitenan, Austria). In: Proceedings Isotopes in Water Resources Manage- ment. Vienna: IAEA. p 379-81.

Schiavo MA, Hauser S, Povinec PP. 2007. Isotope distribution of dissolved carbonate species in southeastern coastal aquifers of Sicily (Italy). Hydrological Processes 21(20):2690-7.

Schiavo MA, Hauser S, Povinec PP. 2009. Stable isotopes of water as a tool to study groundwater-seawater interactions in coastal south-eastern Sicily. Journal of Hydrology 364(1-2):40-9.

Stute M, Deák J, Révesz K, Böhlke JK, Deseö E, Weppernig R, Schlosser P. 1997. Tritium/ ${ }^{3} \mathrm{He}$ dating of river infiltration: an example from the Danube in the Szigetköz area, Hungary. Ground Water 35(5):90511.

Usačev S, Povinec P, Chudý M, Šeliga M. 1973. Bratislava radiocarbon measurements I. Radiocarbon 15(3):443-50.

Vogel JC. 1970. Carbon-14 dating of groundwater. In: Isotope Hydrology 1970. Vienna: IAEA. p 235-7. 